\title{
Sino-Russian Cooperation: Prospects and Issues
}

\author{
Andrey Makarov \\ Transbaikal State University \\ Chita, Russia
}

\author{
Natalia Gusevskaya \\ Transbaikal State University \\ Chita, Russia
}

\author{
Yilin Xie \\ Heilongjiang University \\ Harbin, China
}

\begin{abstract}
This article deals with the prospects and issues of Sino-Russian cooperation in modern conditions. Both China and Russia regard each other as the most important economic and political partner in the international affairs, because of the same or similar interests and opinions in global issues. The authors make the conclusion that Sino-Russian cooperation has prospects in different areas and American factor plays key role in it.
\end{abstract}

Keywords-Sino-Russian cooperation; economic and political partner; international affairs; American factor

\section{INTRODUCTION}

Russia has been living under the conditions of undeclared war on the part of the USA and its satellites for almost two years. One can talk a lot on formal pretext of such "punishment", but it would be better to cite Vladimir Putin's thesis on sanctions from his Address to the Federal Assembly in 2014: "Speaking of the sanctions, they are not just a kneejerk reaction on behalf of the United States or its allies to our position regarding the events and the coup in Ukraine, or even the so-called Crimean Spring. I'm sure that if these events had never happened, they would have come up with some other excuse to try to contain Russia's growing capabilities, affect our country in some way, or even take advantage of it".

After Putin became president again, he took measures to resist foreign interference in Russia's domestic affairs and to maintain domestic political stability. Putin also asserted that U.S. military intervention in internal conflicts in foreign countries has become "common place", he criticized an "American Exceptionalism" that Obama had referred to when he spoke to the nation. He said: "Millions around the world increasingly see America not as a model of democracy but as relying solely on brute force, creating coalitions together under the slogan 'you're either with us or against us.' He has made up his mind to turn Russia into the only world power which is capable of confronting the U.S. Many international scholars admit that today Russia is playing a lone hand in showing up American arrogance, accusing it of double standards on human rights violations and interference in other countries' legitimate internal affairs [4].

Russia's "domestication" attempts are undoubtedly a proving "ground" for testing future deterrence technologies of other countries, first of all, the PRC which is increasingly becoming more powerful. Appraising China's development is often a hot topic in the United States. Some in the United States hold the view that China's development constitutes a challenge to U.S. global leadership. China's political and social systems have long been targets of Americans criticism. After more than 30 years of growth of 9 percent or more, China has become the world's second largest economy and is expected to top the ranking at around 2020. To some American realists, who believe that a strong nation is bound to seek hegemony, China's growing economic strength and its correspondingly higher international influence constitutes a potential threat and challenge to their country's global leadership. American international scholars claim, as long as China maintains its current development speed, confrontations, or even conflicts, between the United States and China are inevitable.

Currently, both China and Russia regard development as the top priority of national policies. By joining hands, they bolster their capabilities, resulting in a strategy of "one plus one is greater than two." China and Russia also find some common grounds in dealing with the United States: They both disagree with the U.S. practice of using force and sanctions to threaten other countries and the double standards applied on itself and others, on its allies and non-allies. As a result, China and Russia usually take similar stances in international affairs.

It is Russia and China consolidating other respectful countries that are the two main forces preventing the American "end of history". They are the main actors of Pax Americana dismantling, formation of the new world order and the new quality of justice in international relations. Therefore, one of the geopolitical aims of the USA is increasing China's strategic vulnerability and disrupting of Russia-China cooperation potential.

\section{DIFFERENCES AND CONFLICTS OF INTEREST ARE WELL- UNDERSTOOD AND KEPT UNDER CONTROL}

There have been two arguments among the international scholars on how to assess and predict the future development of China-Russia relations. One holds that these relations are vulnerable, complicated and filled with uncertainties. Historical issues and misgivings still remain a hindrance towards bilateral relations between both countries. In China, some academics still talk about the 1.5 million square kilometers of land annexed by Tsarist Russia in the late 19th Century, which has 
been recorded in China's history textbooks. They consider recognition the independence of Mongolia as a result of unfair treaty which China was forced to sign in 1945 [5].

Second, China and Russia have different core interests in Central Asia. So far Russia has not taken sides in the dispute over the Diaoyu Islands. China worries that Russia is not going to suspend weapon sales to its ally Vietnam, though Vietnam has maritime disputes with China. Although China has been relatively understanding about Russia's actions in the Ukraine, it will not go too far in its support [10].

In international practices, China and Russia have different styles and focuses. Russia is traditionally oriented toward Europe, which is also its current foreign policy priority, whereas China is more focused on Asia. Russia's foreign policy style that is more on the tough side, and sometimes more in an unexpected direction. In comparison, China's diplomatic moves are more conservative. Naturally this has to do with different levels of perceived pressure in each country's respective security arena. Moreover, in recent years, China has continued to deepen cooperation with other members of the CIS, which might have given Russia the impression that itis competing for influence.

On the other hand, some believe that it is inevitable that the two countries, both under heavy U.S. pressure will create an anti-Western alliance. Such an alliance, according to those suspicions, would be aimed at dethroning the United States from its leading position in the world and thereafter shaping a new world order. An article published on the U.S.-based Business Insider website even proposed nine ways in which China and Russia could undermine the United States [3]. The proposals included massive military as well as nuclear forces buildup, the consolidation of territorial claims, and the support of «rogue regimes" both economically and militarily. In addition, waging cyber warfare worldwide, indirectly facilitating terrorist groups and obstructing the UN's decisionmaking process were deemed as likely methods for causing havoc.

In response to such accusations Beijing claims that China does not pursue policies of bloc or alliance politics, nor do they have such a political culture in action.

Russian view on Russian-Chinese cooperation described President Putin. In his article "Russia and the Changing World" he suggested that Russia needs a prosperous and stable China, while China needs a strong and successful Russia. President Putin proposed to allow the Russian Economic sail "multiplied by the rapid development of the wind", "potential" for Russia's Siberia and the Far East economic rise on further attempt of developing the Sino-Russia relations. At the envoys conference on July 9, 2012, Putin said: "strategic cooperation and practical cooperation with the People's Republic of China is on top of the agenda, we will pay special attention to deepen the opportunities for cooperation with China."

\section{CHINA AND RUSSIA MANAGE THEIR COOPERATIVE RELATIONS FROM A PERSPECTIVE OF LONG-TERM AND STRATEGIC}

On March 23, 2013, Chinese President Xi Jinping said when speaking at the Moscow State Institute of International Relations (MGIMO) that the Treaty of Good Neighborliness and Friendly Cooperation Between the People's Republic of China and the Russian Federation had laid a groundwork for the long-term development of Sino-Russian cooperative partnership. Currently, both China and Russia are experiencing an important period of national revival, and bilateral relations have entered a new stage characterized by the fact that both countries present important strategic opportunities for each other and are major priority partners of each other [9].

It is worth noting that in recent history there were ups and downs in Russian-Chinese relations. In 1950 the Soviet Union and the newly founded People's Republic signed the SinoSoviet Treaty of Friendship, Alliance and Mutual Assistance. The Soviet Union provided strong support for the rebuilding of the new China. However, due to the fact that both sides tended to put ideology before national interests, the alliance fell into crisis within its first decade.

In the 1980s, the Soviet Union and China started negotiations on normalization of diplomatic relations, and former Chinese leader, Deng Xiaoping, put forward the basic principle for relations between the two countries, namely, "independency, full equality, mutual respect and noninterference in each other's internal affairs. «In May 1989, Mikhail Gorbachev, then General Secretary of the Communist Party of the Soviet Union, visited China and accepted China's proposition. The two countries then jointly reaffirmed that they would develop bilateral relations based on the principle of "mutual respect for sovereignty and territorial integrity, mutual non-aggression, non-interference in each other's internal affairs, equality and mutual benefit, and peaceful coexistence." [5]

After the collapse of the Soviet Union in 1991 for the newborn Russia the idea of a return to Atlanticism was the predominant view in the beginning, advocating that Russia's adoption of the Western system was in accordance to its national interests. That meant the Russian foreign policy would henceforth look to the West. Kremlin believed that Russia's key partners should be wealthy developed countries with mature economies and democratic systems, i.e. the United States, West Europe and Japan. To win the trust and help of the West, Russia actively responded to the U.S. and European requests and made concessions on major issues including economic reform, reduction of strategic nuclear weapons, withdrawal of troops from the three Baltic countries (Estonia, Latvia and Lithuania) and imposing sanctions on Iraq. Boris Yeltsin and U.S. President Bill Clinton issued the Vancouver Declaration, announcing their firm commitment to "a dynamic and effective U.S.-Russian partnership, turning from Cold War opponents to strategic partners. In 1994, the two sides issued the Moscow Declaration, announcing that their relationship "entered a new stage of mature strategic partnership" and they would no longer target their nuclear missiles at each other. According to a survey conducted by Levada-Center, a Russian independent polling and sociological research organization, at 
that time, the Russian public had good impressions and high expectations of the U.S. The respective proportions of Russians who liked and disliked the U.S. were 80 percent and 6 percent. However, Russian passion for the West turned out to be wishful thinking in that they received no more than lip service.

Since the collapse of Soviet Union, the U.S has tried to hold on to its global hegemony, advocating overseas interference and using force at every turn. The U.S. has regarded Russia as its vital geopolitical rival for a long period. On one hand, the U.S. has been squeezing Russia's geopolitical space through an eastward expansion of NATO. After two rounds of eastward expansion, NATO absorbed three Baltic countries, Central and East Europe, as well as the main Balkan countries, and the new political and security order there became dominated by NATO. On the other hand, the U.S. promoted "democratic revolution" in former Soviet countries through such means as "color revolution" and "aid for democracy" to try to prevent those countries from being influenced by Russia again [2].

Therefore, Russia sought to rebalance and diversify its foreign relations as well as resume more active relationships with its neighbors and countries in East Asia. At the end of 1992, Russia put forward the "double-headed eagle strategy" to simultaneously look to the West and East. In December 1992, Yeltsin visited China and met with Chinese leaders for the first time. During his visit, the two countries announced that they would «regard each other as a friendly country. «In 1994, the then-Chinese President Jiang Zemin visited Russia and the two sides declared the establishment of «constructive partnership featuring good neighborliness and mutually beneficial cooperation. Since then, China-Russia relations had been put on the fast track and were upgraded every few years, with their cooperation areas continuing expanding. In 1996, the two countries decided to develop a "partnership of strategic coordination based on equality and mutual benefit which was oriented toward the 21 st century. In 2001, the Treaty of Good Neighborliness and Friendly Cooperation Between the People's Republic of China and the Russian Federation was signed, which stated that they would develop the "strategic cooperative partnership of good-neighborliness, friendship and cooperation and equality and trust between the two countries from a longterm view and in a comprehensive manner'. In 2014, leaders of the two countries jointly issued a declaration, stressing that China-Russia relations have entered a new stage of comprehensive strategic partnership of coordination. They agreed that, the freedom of people to choose their own development paths should be respected, while differences in social systems and ideology should not hamper the normal development of relations. By setting such fundamental and commonly shared principles, China and Russia were able to gradually resolve differences and conflicts. For instance, the two countries completed the 40-year marathon-style border negotiations in 2008, peacefully resolving territorial disputes that have troubled the two neighbors for decades. By demarcating the 4,300-kilometer-plus borderline, the two countries had eliminated the biggest obstacle and hazard for bilateral relations. Equality and mutual respect bred a high degree of political confidence, and made it possible for the two countries to have unconstrained, direct and candid bilateral dialogues at all levels. Since 2013, President Xi has paid four visits to Russia. Plus meetings on the sidelines of multilateral occasions, the two heads of state have already met 14 times. Putin has become the foreign head of state that $\mathrm{Xi}$ met most frequently since assuming the Chinese presidency. Russian President Vladimir Putin will combine his participation in the Beijing Forum "One Belt, One Road" with a working visit to China in May, 2017. Chinese President Xi Jinping in the middle of this year will pay an official visit to Russia. The General Office of the CPC Central Committee and Russian Presidential Executive Office also established cooperative relations, which is rare in China's external contacts. Chinese President Xi Jinping and his Russian counterpart Vladimir Putin sent congratulatory messages to the sixth meeting of the China-Russia inter-party dialogue mechanism and the fifth China-Russia inter-party forum, both of which were held on March 23, 2013 in Kazan, Russia. In his message, Xi said that China and Russia should continue their lasting friendship and stand firm in deepening the comprehensive strategic partnership of coordination between the two countries.

On 7 November, 2016, the 21st regular meeting of the Russian and Chinese heads of government was held in St Petersburg. Dmitry Medvedev and Li Keqiang detailed discussions of the key issues of Russian-Chinese trade, economic, investment, energy, humanitarian, interregional and cross-border cooperation.

Now when the Chinese and Russian leaders met at various levels, the promotion of functional cooperation was always the central topic on the table. From 1991 to 1995, the bilateral trade volume was less than $\$ 5$ billion and primarily in the form of barter trade. In 2014 , it came close to $\$ 100$ billion, a nearly 20 -fold increase in 20 years. In 2014, China and Russia signed a landmark contract on constructing a natural gas pipeline on the eastern route. From 2018, Russia will start to supply natural gas to China for 30 years via the eastern route, which will have a maximum transportation capacity of 38 billion cubic meters per year. The two countries signed a technical agreement on Russia's supply of natural gas to China via the western route. Both countries were planning more "big deals" in fields such as finance, nuclear power generation, aerospace manufacture, high-speed rail, and infrastructure development. A 2015 statistics from the Russian Public Opinion Research Center showed that, 66 percent of Russians thought that China would replace Western countries to become Russia's main economic partner.

But more than 2 years after the two countries initiated most of their bilateral projects, there has been no significant progress, and some projects have been abandoned altogether. At the moment Russian-Chinese cooperation can be characterized by "hot politics and cold economics." It should be noted that in 2015, China has invested in the Russian economy \$794 mln, which is only $0.7 \%$ of its total investments abroad ( $\$ 116 \mathrm{bln}$ ). Also, in January-September 2015 Russia's export of natural gas to China dropped seriously: by $51.3 \%$ in absolute terms and by $71.5 \%$ in value. The overall decline of Russia's turnover with China can reach $30 \%$ by results of 2015 . From January to May 2016, bilateral trade amounted to $\$ 25.8$ billion; it ceased to decline and grew by 2.7 percent compared to the same period last year. 
Nonetheless, $\$ 200$ billion by 2020 is still the plan, according to Foreign Minister Sergei Lavrov in May, 2016. From the development of Russian-Chinese economic and trade relations western analysts doubt that it is quite possible to achieve the goals [1].

In 2013, China put forward the Silk Road Economic Belt initiative, and Russia has worried that it might divert attention from the Eurasian Economic Union (EEU) that it initiated. Two countries have to agree to align the two initiatives for the common good of the region. Kremlin insists that "Silk Road plan" combined with the Russian Trans-Siberian Railway will be a win-win. Significant progress was achieved in strengthening the interconnection of infrastructure with regard to aligning the strategies for reviving Northeastern China and for developing the Russian Far East [7]. While helping develop the Russian Far East and adding to China's economy, the expanding bonds between China and Russia have far-reaching geopolitical significance. However, the full potential of the Sino-Russia relations is yet to be uncovered. There is much work to be done in this regard. According to experts, there are two issues in the Russian-Chinese cooperation. The Russians do not understand the Chinese mentality, while Chinese businessmen tend to dominate in business. To summarize, differences and conflicts of interest still exist but should be well-understood and kept under control.

\section{THE DEVELOPMENT OF SINO-RUSSIAN COOPERATION IS GEARED TOWARDS REGIONAL AND WORLD PEACE}

Moscow and Beijing avow that strategic partnership is the imperative for both countries. However, despite the significant agenda in Russian-Chinese cooperation, the parties will have to realize the actual degree of interdependence. Unfortunately, today China takes Russia in a situational ad hoc format. Nevertheless, transformation of Ukraine into a failed state and the so-called "Arab Spring" clearly demonstrate a significant destructive resource of the USA and the collective West in general. The latest events show that both the Middle East and Southern Asia are "open" to destabilization.

Meanwhile, China has taken its place as the world's second largest economic entity and the American foreign policy began to treat China as its most powerful rival. In this regard, ambitious Beijing's plans to implement "the Silk Road Economic Belt" might be unrealizable without considering Moscow's opinion on necessity of the Chinese grand project and the Eurasian Economic Community connection. An attempt to make the whole of the Eurasian continent a development zone is most likely to be destined to fail without this connection. The question is not that somebody will make problems out of Eurasia's economic integration along the southern route. The fact is that these problems have already been made.

The Government of the People's Republic of China is worried about the fact that the Great War in the Muslim world will once and for all block the ground Silk road to Europe deadening a shipping in the Strait of Hormuz passing more than 17 million barrels of oil daily. "In the 20th century the Pentagon repeatedly used this artery which is only 33 kilometers (21 miles) wide. America is ready to stoke up a furnace with any state in the region to weaken the global power competitiveness" [8]. In the aftermath of antagonism outbreak between Iran and Saudi Arabia, Zhang Ming, a Vice Minister of Foreign Affairs for West Asia and North Africa, visited these countries. The Ministry of Foreign Affairs of China officially declared: the PRC hopes that situation in the Middle East will stabilize and the parties will maintain peace. However, it is difficult to make plans sitting on a gasoline barrel. The Great War in the Middle East and the follow-up continuous regional war of "all against all" format is not an illusion.

China is afraid of the Russian economy unpredictability for good reasons. A Chinese analyst Zhao $\mathrm{Yu}$ in his article "Commentary: Will Russia Be Able to Pass a Strength Test Against the Background of a Difficult Crisis?" cites a viewpoint of Feng Yujun, director of the Institute of Russian Studies at the Chinese Academy of Contemporary International Relations. In his opinion, Russia has been at the most serious strategic deadlock since the early 21 st century because of the Ukrainian crisis. The sharp slide in oil prices together with the Western sanctions has led Russian economy to "depression". Distrust has considerably increased in Russian-American relations. Finally, Russia and NATO have started to treat each other as strategic antagonists as it was in former times. In the short- and medium-term perspectives, according to the article, it would be difficult for the West to change its general policy towards Russia [11].

This publication has drawn a wide response in Russia and has become a ground for dishonest interpretation by the socalled liberal mass media beginning to speculate on statements about the Russian economy crash accusing "the Kremlin's totalitarian regime". Actually two stimulating factors may make the Russian economy worse: the fall in international oil prices has led to and will continue to produce a major negative impact on the Russian economy, which depends excessively on the export of natural resources. Second, EU and US sanctions will gradually bring about series of impacts on Russia. But every story has two sides. This situation may also become a driving force for structural reform in Russia, forcing the country to seek more resolutely to rid itself of its dependence on energy export and to take a normal and healthy road to revival as early as possible.

But the point is that the current problems of Russia shouldn't cover their possible collaterality. Safety of the country, its strategic state (at a deadlock or in dynamics of development) depend not only on the economic and political situations created in a concrete period, but also on its military, geopolitical and even a territorial component. It should be noticed that probable extreme scenarios of the Great War in the Middle East can suit Russia more than its other participants. It is because Russia has no multibillion investments into economy of the region and, along with shortcomings, it has very convincing strengths. It is about "a gun" which is hanging on the wall during a performance but, according to the Russian classical writer Anton Chekhov, it must fire in the last. Russian literature was notable for a very keen insight. At least, the Syrian operation of Russia during which the country involved part of its military potential is an example of reformatting of a situation in the key region of the world in its interests. 
Possible repartition of the Middle East will generate a new geopolitical situation and new formats of economic reality. Russia along with inevitable challenges is capable to get a bonus in the form of a reasonable oil price. In the course of these changes, the so-called Ukrainian crisis is thought to be regulated, at least in a purely utilitarian sense. Degrading archaic Ukraine will become the territory available for economic development in interests of Russia, China, Europe and Eurasia in general. Current Ukrainian crisis is not at all the evidence of a strategic deadlock of Russia, but it is rather a beginning of the break in the deadlock, a sharp phase of mental recovery, finding of geopolitical sanity and reasonable impudence.

In Vladimir Putin's resonant interview with the German newspaper Bild, he called the main mistake in Russian foreign policy during the last 25 years: "We have failed to assert our national interests, while we should have done that from the outset. Then the whole world could have been more balanced". It is obvious that Russia has started correcting this fundamental mistake.

Sergey Karaganov, Dean of the Faculty of World Economy and International Affairs at National Research University Higher School of Economics, thinks that "the last year was one of the most successful in the history of Russia's foreign policy". In the expert's opinion, "there is accustoming to a new reality and new rules of the game with Russia based on respect for interests". In this thesis context, it is worth agreeing with S. Karaganov's point of view: "New attempts to untwist the Ukrainian crisis are possible. But Russia has stood the first round of opposition and pressure. And in general, in the conflict round Ukraine it has politically won" [6].

According to the official Xinhua publication mentioned above, in the nearest foreseeable future, the USA will possibly impose a strategic deadlock on China, and Russia with its allegedly "ragged economy" taking into account American domestic and foreign problems, as an object of pressure will be pushed to the sidelines. One cannot destroy what was destroyed in the early 1990s and has been in the beginning of its development so far, tending not to be affected by a global external action. All that our "Western partners" could do against Russia has already been done - they have limited access to the financial markets and collapsed in energy resources prices. These are the two major factors which really negatively influence our country. It is these facts that Vladimir Putin emphasized in the interview with Bild mentioned above.

Globally, the USA is not ready to make any compromise. It will continue to get world economy under it within the framework of the Trade in Services Agreement (TISA), the socalled Trans-Pacific partnership directed on pushing the PRC out of the American market and the markets of other parties and, mainly, within the framework of NAFTA (the USA, Canada, Mexico) association with the European Union in a single free trade and investments area. The motivation for the US to boost and dominate TPP negotiations promotes higher level trade and investment liberalization and blocks China from dominating future international rules. Obama was blunt: "When more than 95 percent of our potential customers live outside our borders, we can't let countries like China write the rules of the global economy. We should write those rules, opening new markets to American products while setting high standards for protecting workers and preserving our environment.",

They will lie and damage openly or surreptitiously: as in case of slumping oil prices, as in case of the $\mathrm{Su}-24$ jet which was shot down over Syria by the Turkish fighter and it may happen that in case of the plane crash of Kogalymavia flight 9268 over the Sinai Peninsula which was pompously and without any regret covered in the Western mass media as an inevitable payment for Russian "invasion into Syria". The degree of the USA passion for its own exclusiveness and aiming at absolute hegemony clearly demonstrate the fact that Vladimir Putin who used to be a rather pro-Western politician has been declared their enemy without a second thought.

In this regard, very painful but fast changes can be more advantageous than less painful but long and exhausting ones. Rational China thinks mainly in terms of economy, it builds policy taking into account its economic expansion, professing some kind of aggressive pragmatism. But, very often, the economy shows political impotence in understanding the main world actors. In this sense, China's effort to work in many competitive directions can develop into disappointing dissipation of resources and unfounded hopes.

Today Russian-Chinese cooperation reminds a marriage of convenience. And though such marriages are the strongest, the convenience has to be supplemented with the development of humanitarian cooperation and big mutual recognition. It is very important that the idea of the Russian-Chinese strategic partnership would be increasingly supported by the broadest strata of Russian society.

Russia is sure to concede to China in respect of opportunities and resource readiness for development of multilateral humanitarian cooperation where China is objectively capable of playing the first fiddle. This should not concern a sly Western approach which adds up to recruitment and training of agents of influence. At the same time, such cooperation shouldn't be reduced only to demonstration of the Celestial Empire achievements and capacity. Its important direction could be the support of socially oriented projects, which will be welcomed in Russian society.

It is important that the Russian-Chinese partnership has a long and proud history bringing us closer. Russia and the People's Republic of China together celebrated the 70th anniversary of the end of World War II. On May 9, 2015 the Chinese President Xi Jinping visited Moscow and became the number one guest at the Great Victory Parade and other celebrations devoted to the most important date in the Russian history of the 20th century. On September 3, 2015 Vladimir Putin was present at the celebration of the 70th anniversary of the victory of the Chinese People's War of Resistance against Japan and the end of World War II. The USSR gave invaluable support to China in fight against Japan. A feat of labor of the Soviet people during the Great Patriotic War became a pledge of the Great Victory.

Participation of the Chinese institutes in preservation of this feat memory and, thereby, their contribution to preservation of 
value orientations within which modern Russian patriotism is built would become significant investment into strengthening of the Russian-Chinese relations. It is such patriotism that builds up the Russian nation immunity from national betrayal of elite which, unfortunately, the Russian history is rich in. Meanwhile, repetition of the 1991 scenario assuming dismantling of the Russian-Chinese alliance is a priority problem of our "Western partners" and their influential "fifth column".

\section{CONCLUSION}

At first sight, with respect to a situation of modern RussianChinese rapprochement, present American foreign policy strategists can be asked citing V. Putin: "Do you at least realize now what you've done?" The West's thoughtless policy indeed plays into the hands of relations between Russia and China. The USA encourages us as if intentionally to integrate mutually both in politics and the economy. But it would be too naively to expose them being silly. Playing upon differences between our countries, using a tough-minded pragmatism of China on the one hand and inconsistency and insufficient competence of some Russian officials on the other hand, it is possible to miss the right moment and possibilities for further rapprochement of our countries.

Friendly Russia, which China needs is a strong and sovereign Russia. There will not be such China's ally in the foreseeable future. It is for this reason that the People's Republic of China has to be ready to support Russia at any development of the Middle East scenario, mutually advantageous for both countries, and to approach the country's policy in relation to Russia in a more creative constructivist key.

\section{REFERENCES}

[1] Catherine Putz, "What Is China and Russia's Eternal Friendship Worth?", The Diplomat, 27 June 2016.

[2] Donnacha Ó Beacháin, Abel Polese, "The Colour Revolutions in the Former Soviet Republics: Successes and failures", London and New York: Routledge, 2010.

[3] Douglas E. Schoen and Melik Kaylan,"9 Ways China and Russia Are Partnering to Undermine the US," Business Insider, 21 January 2015.

[4] Feng Yujun, "Russia-U.S. Rivalry in the Context of Power Imbalance", CIR, Vol.24, No. 3(May/June 2014), pp 1-15.

[5] Fu Ying, "Are China and Russia Axis or Partners?", CIR, Vol. 26, No. 1 (January/February 2016), pp 1-31.

[6] Karganov Sergey, "It's early to celebrate so far", Rossiyskaya Gazeta, 12 January 2016, p. 4.

[7] Lixin, "Chinese perspective on the creation of a Eurasian economic space". Valdai discussion club report, Moscow, November, 2016

[8] Sarkis Caturjan, "The USA menaces China war in the Strait of Hormuz", REGNUM, 10 January 2016.

[9] Xi Jinping. Governance. Beijing: Publishing House of literature in foreign languages, 2014.

[10] Xing Guangchng, "The Ukrainian Crisis in 2015 and Russia's choice", CIR, Vol. 25, No. 2(March/April 2015), pp 82-85.

[11] Zhao Yu, "Will Russia Be Able to Pass a Strength Test Against the Background of a Difficult Crisis?", Xinhua, 12 December 2015. 